
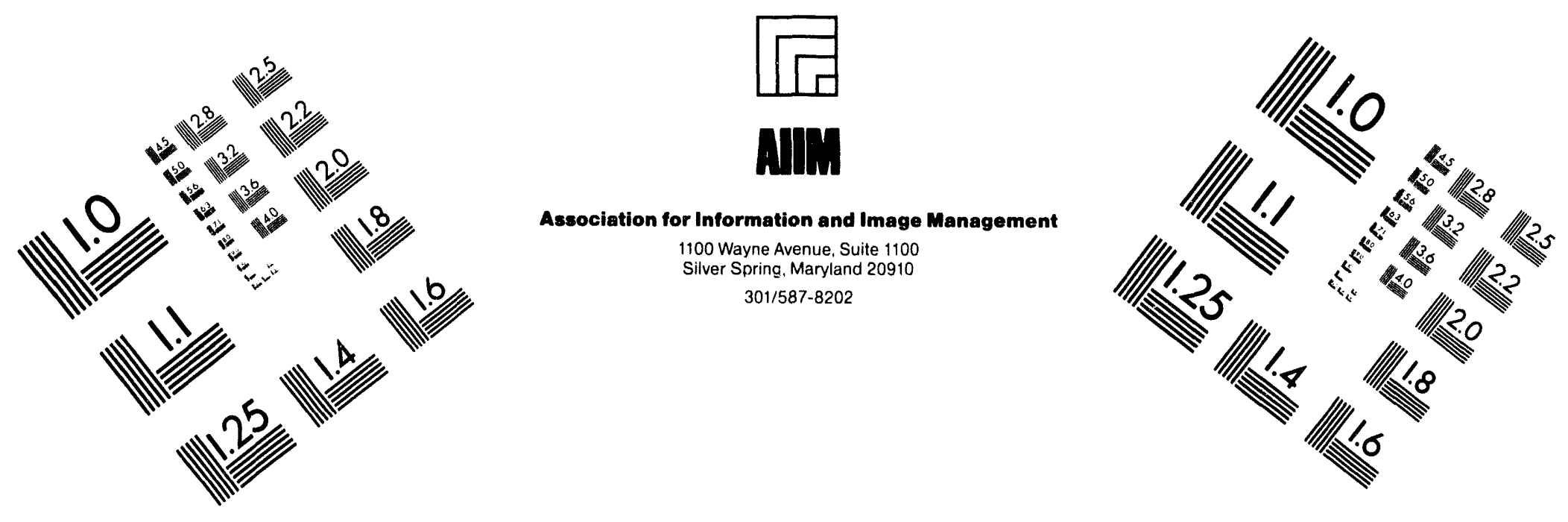

\title{
Centimeter
}

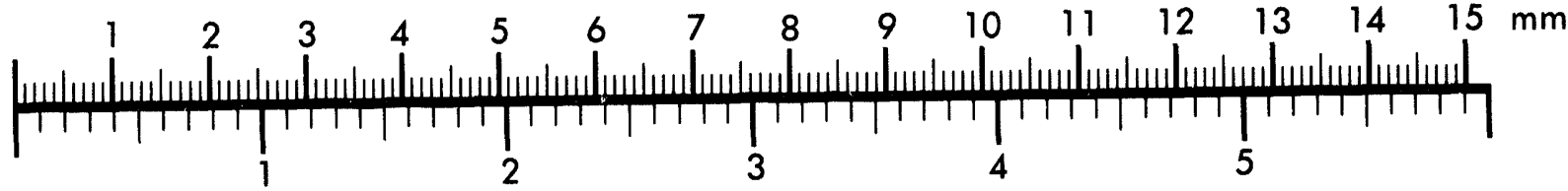
Inches
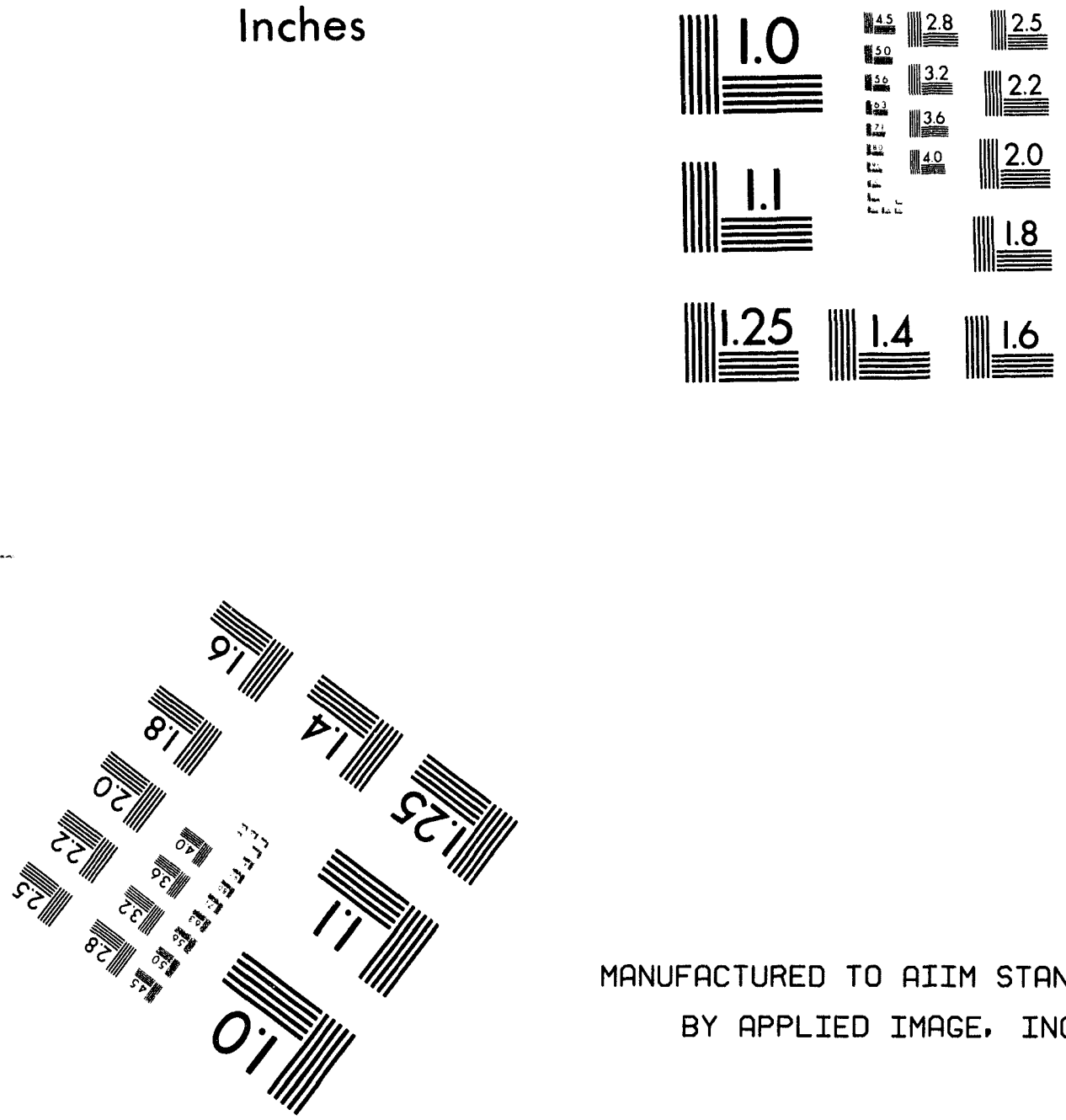

MANUFACTURED TO AIIM STANDARDS

BY APPLIED IMAGE, INC.

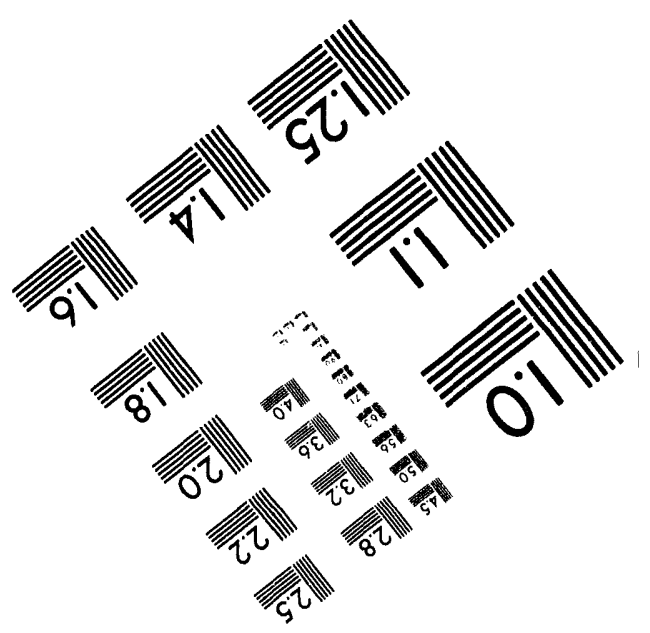



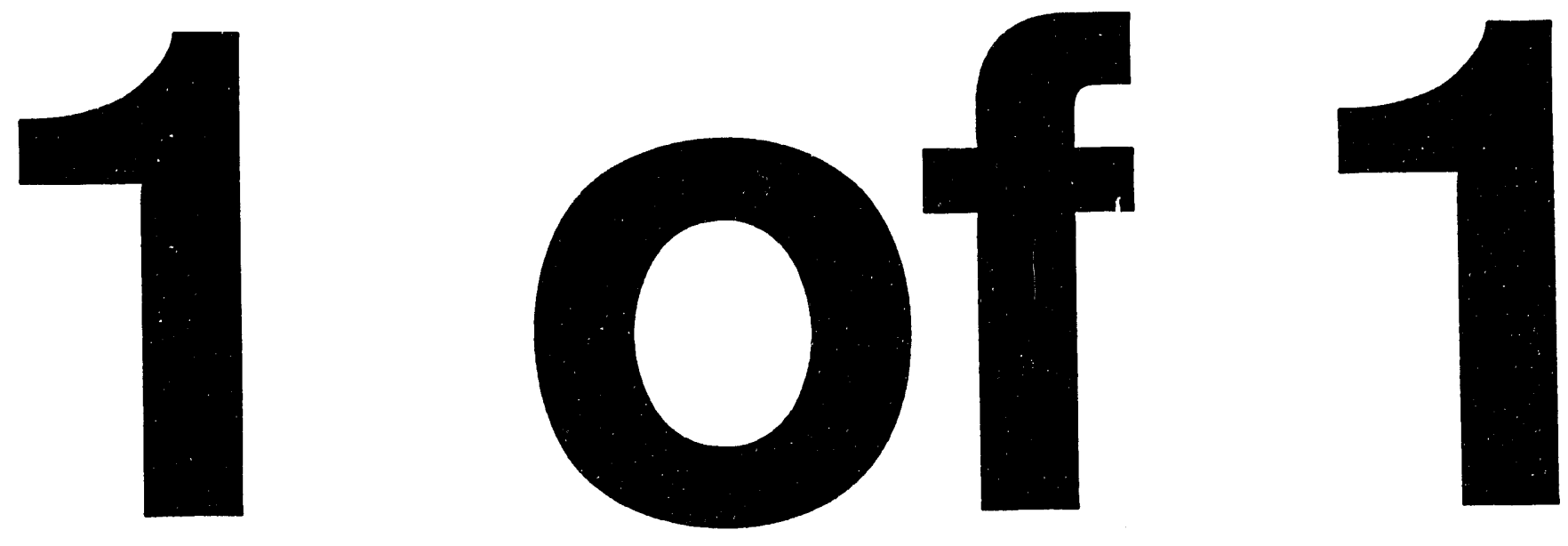
PNL-9412

UC-600

\section{Experimental Plan and Construction Guidance for Hanford Protective Barrier Test at Hill AFB, Utah}

R. R. Kirkham

G. W. Gee

April 1994

Prepared for

the U.S. Department of Energy

under Contract DE-AC06-76RLO 1830

Pacific Northwest Laboratory

Richland, Washington 99352

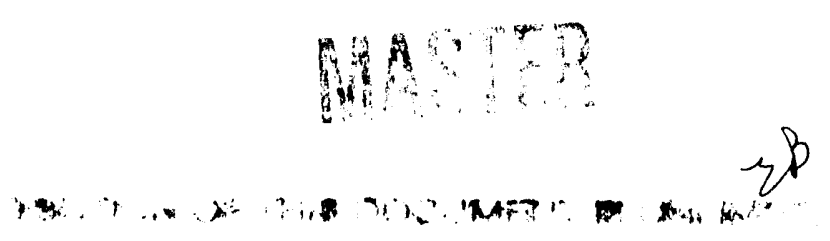




\section{Summary}

Permanent isolation surface barriers are needed to fully isolate buried waste materials for long periods of time from the general environment. Multi-layer surface barriers that use natural earthen materials overlying bio-intrusion layers of rock and/or asphalt are expected to reduce infiltration or deep percolation to less than $0.5 \mathrm{~mm}(0.02 \mathrm{in}$.) of water. The layering also reduces root penetration, preventing uptake and translocation of hazardous materials to the surface vegetation.

The development of these surface barriers is outlined in the Permanent Isolation Surface Barrier Development Plan (Wing 1994). It is necessary to document the effectiveness of the barriers in the Hanford Site environment as it is now, and as it would be, under a wetter environment (a possibility from historical climate analysis and projected by some global climate change scenarios) that stresses the barrier.

The opportunity exists to test the Hanford Barrier in a wetter, colder climate at an existing lysimeter facility located at Hill Air Force Base near Salt Lake, Utah. The use of an existing lysimeter facility simplifies the construction effort and allows comparison of the Hanford Protective Barrier with an existing U.S. Environmental Protection Agency-Resource Conservation and Recovery Act clay cap already undergoing tests at the lysimeter site. This document presents the experimental plan for testing the Hanford Protective Barrier in a wetter, colder climate. 


\section{Contents}

Summary $\ldots \ldots \ldots \ldots \ldots \ldots \ldots \ldots \ldots \ldots \ldots \ldots \ldots \ldots \ldots \ldots \ldots \ldots \ldots$

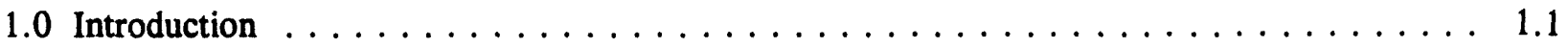

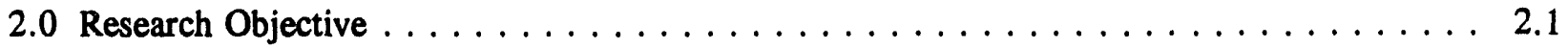

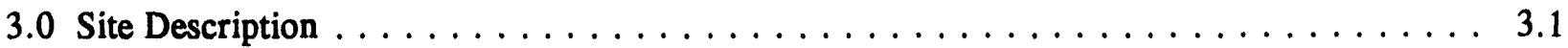

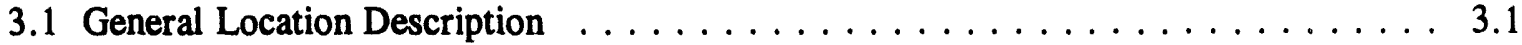

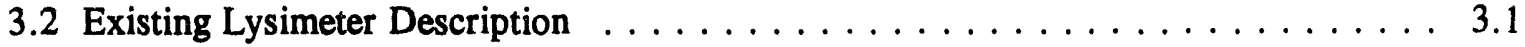

4.0 Lysimeter Design $\ldots \ldots \ldots \ldots \ldots \ldots \ldots \ldots \ldots \ldots \ldots \ldots \ldots \ldots \ldots \ldots \ldots \ldots$

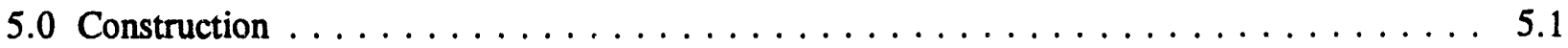

5.1 Lysimeter Step-by-Step Construction $\ldots \ldots \ldots \ldots \ldots \ldots \ldots \ldots \ldots \ldots \ldots$

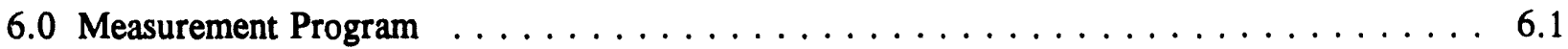

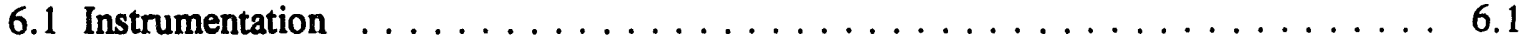

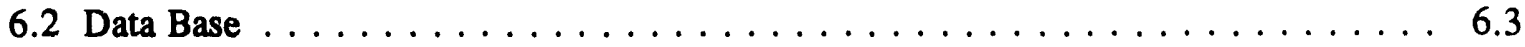

6.3 Quality Assurance $\ldots \ldots \ldots \ldots \ldots \ldots \ldots \ldots \ldots \ldots \ldots \ldots \ldots \ldots$

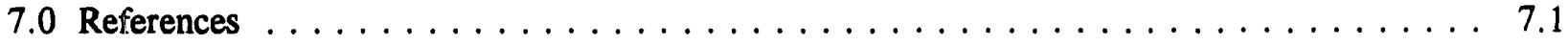




\section{Figures}

3.1 Map of Hill Air Force Base near Ogden, Utah $\ldots \ldots \ldots \ldots \ldots \ldots \ldots$

3.2 Perspective View of New Hanford Barrier Lysimeter (HPB) and Existing

EPA-RCRA Lysimeters $\ldots \ldots \ldots \ldots \ldots \ldots \ldots \ldots \ldots \ldots \ldots \ldots \ldots$

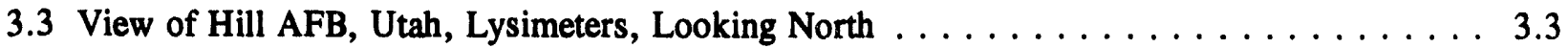

4.1 MathCad File of Dimensions and Volume Calculations for Lysimeter Layers $\ldots \ldots \ldots$. . . . . 4.2

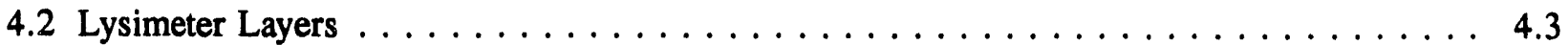

5.1 Plan View of Lysimeter Construction Drawings $\ldots \ldots \ldots \ldots . \ldots \ldots$

5.2 Elevation View of Lysimeter Construction Drawings $\ldots \ldots \ldots \ldots \ldots \ldots$

\section{Tables}

6.1 Instrumentation Measurement Capabilities $\ldots \ldots \ldots \ldots \ldots \ldots \ldots \ldots \ldots \ldots$ 


\subsection{Introduction}

Permanent isolation surface barriers have been proposed as physical barriers designed to prevent transport of hazardous waste out of confinement into the general environment. Transport pathways that are addressed by the barrier include water infiltration, biointrusion, wind and water erosion, human excavation, and gaseous release. Permanent isolation barriers are needed for final disposal of several types of radioactive waste forms found on the Hanford Site in southeastern Washington. This geographical region lies in the rain shadow of the Cascade Mountains and precipitation averages $160 \mathrm{~mm}(6.30 \mathrm{in}$.) per year. The Hanford Site is a cold desert with most of the precipitation occurring during the winter months. Long-term hydrologic simulation reported in the Final Environmental Impact Statement for the Disposal of Hanford Defense High-Level, Transuranic, and Tank Wastes (DOE 1987), indicates the need to limit infiltration to $0.05 \mathrm{~cm}(0.2$ in.) per year.

Lysimeter studies (Gee et al. 1993a) testing the barrier design have been under way for over 6 years. The barrier proved effective under natural and 2 times normal precipitation. Drainage was only observed on the non-vegetated treatment when precipitation was elevated to 3 times normal. These lysimeter tests are not fully representative of a wetter climate for three reasons. First, the irrigated area of the lysimeter complex is small and advection of sensible heat (warm, dryer air) may artificially elevate the evapotranspiration rate associated with the irrigated treatments. Secondly, the application of irrigation does not simultaneously reduce the solar radiation as would be typical of rainfall and the associated cloud cover. The third inadequacy deals with the form of the added precipitation. The lysimeters have received additions of above-normal precipitation as a liquid (irrigation), not as a solid (snowfall). Snow will not infiltrate until it melts, allowing time for sublimation to return water to the atınosphere reducing the amount of water entering the soil profile.

Therefore, the Hanford Site, with a dryer climate either slightly warmer or cooler, will have less water available for deep recharge. Likewise, a wetter and warmer climate will have less drainage than a wetter, colder climate. This analysis indicates, for climatic change testing, the wetter colder climate would be the worst-case test. Such testing can best be achieved by placing a test lysimeter in an area with a wetter, colder climate. Testing of the Hanford Protective Barrier under a wetter climate is more realistic than the supplemental irrigation treatments at the Field Lysimeter Test Facility (FLTF), located on the Hanford Site, where "oasis effects" (an elevated rainfall environment may be adversely affected by horizontal transport of energy from the surrounding larger natural environment) may have increased evapotranspiration above normal.

Development of a plan to test the Hanford Protective Barrier in a wetter environment is an important task objective designed to complement the current work at the Hanford Site on surface barrier development (DOE 1993; Wing 1994). This experimental plan describes the testing of the capillary barrier component of the Hanford Protective Barrier in a wetter climate (northeastern Utah) with three times the average annual Hanford snowfall. Other barrier designs have been tested at this site [Hill Air Force Base (Hill AFB)] since 1989, and significant drainage occurs in these lysimeters under ambient (non-irrigated) levels of precipitation (Hakonson et al. 1993).

The Hanford Protective Barrier is an aboveground cover system, designed to isolate buried hazardous materials from the environment. The current (1993) configuration provides a robust 
multi-purpose barrier designed to limit percolation and biotic intrusion. The major features of this barrier include a capillary-barrier (i.e., silt loam over coarse sand/gravel), bio-intrusion resistant rock sublayers, and a low-permeability asphalt layer (Gee et al. 1993a).

The surface silt loam soil layer acts as a hydrologic barrier by storing annual precipitation until it can be removed through soil evaporation and water loss through plant leaves (transpiration). The combined water loss, termed evapotranspiration (ET), is a critical component of the barrier water balance. With proper design, barrier ET can annually match precipitation, provided there is an adequate storage capacity in the soil. To reduce drainage and effectively increase the storage capacity of the silt loam soil, sublayers of coarse sands and gravels are included. Redistribution of soil water in response to gravity slows as soil water content decreases or the conductivity of the medium decreases. The addition of coarse sand and gravel layers creates a hydrological barrier to unsaturated flow because the coarse materials conduct less water than the finer soil at water contents less than saturation. Below the gravel layer, a bio-intrusion barrier is included that is constructed from large rocks which are not readily removed by people or animals. Large rocks have such low water holding capacities that roots are not expected to penetrate or maintain a viable root system in an arid or semi-arid environment. In the complete implementation of the Hanford Protective Barrier, a second hydrologic barrier is included consisting of a layer of low-permeability asphalt.

Construction is expected to begin on a large 2.5-ha (6.17-ac) test barrier at the Hanford Site in early 1994. Prototype testing will include studies of water balance, wind and water erosion, and biointrusion (Gee et al. 1993b). Concurrently, as described in this test plan, a large-scale lysimeter [5 by $10 \mathrm{~m}$ ( 16.4 by $32.8 \mathrm{ft})$ ] will be constructed at Hill AFB using the same soils, plant species, surface soils, and medium-sized coarse layers, but subjected to a climate which has three times the average annual precipitation arriving predominately as winter snow. The asphalt and bio-intrusion rock layers will not be included in this lysimeter.

This experimental plan presents the construction, instrumentation, and measurement program for this large-scale lysimeter. The test of the Hanford Protective Barrier at Hill AFB will be documented carefully and lysimeter results will be compared with ongoing monitoring of a U.S. Environmental Protection Agency (EPA) Resource Conservation Recovery Act (RCRA) cap already existing in a similar lysimeter at this site. The comparison of the Hanford design and the RCRA cap will provide a measure of equivalency between the two cap designs under Hill AFB environmental conditions. 


\subsection{Research Objective}

This experiment is directed at measuring the effectiveness of the Hanforc' Protective Barrier in preventing drainage of annual precipitation under a wetter and colder climate scenario. Previously, this condition has been simulated by increasing precipitation amounts through the application of supplemental irrigation at the FLTF and the Small Tube Lysimeter Facility, also located on the Hanford Site. During these applications, there has been no attempt to reduce the solar radiation and air temperatures or increase ambient vapor pressures. Such changes in environmental variables can be expected in association with increased precipitation in a wetter, colder climate. Note that evapotranspiration is, in part, controlled by available energy (air temperatures and solar radiation) and vapor pressure gradients, and that the previously mentioned adjustments to these driving forces will tend to decrease evapotranspiration rates.

By testing the Hanford Protective Barrier at Hill AFB, we will effectively simulate a climatic change without costly environmental modification. In addition, the existence of the RCRA cap will allow direct comparison of the two barrier designs under the same climatic conditions. 


\subsection{Site Description}

\subsection{General Location Description}

The Hill AFB is located in northeast Utah (Figure 3.1), in the southwest part of the Weber Delta District with portions of the base in both Weber County and Davis County. The base is situated on a broad plateau between the Great Salt Lake and the Weber River Valley. The plateau is part of the Weber Delta, formed as the Weber River flowed into Lake Bonneville [ancient Pleistocene lake with stable elevations of 1585 and $1463 \mathrm{~m}$ (5200 and 4800 feet)]. Surface soils are generally loamy fine sand or fine loamy sand. The soils are deep and well drained.

Summer weather is hot and dry [maximum temperature $40^{\circ} \mathrm{C}\left(104^{\circ} \mathrm{F}\right)$ ], and winters are cold with a generally stagnant air mass [minimum temperature $-81^{\circ} \mathrm{C}\left(-13^{\circ} \mathrm{F}\right)$ ]. Annual average rainfall is $48.8 \mathrm{~m}$ (19.2 in.) and annual average snowfall is $182.4 \mathrm{~cm}(71.8 \mathrm{in}$.$) .$

\subsection{Existing Lysimeter Description}

In 1989, Los Alamos National Laboratory (LANL) built four lysimeters at Hill AFB. The four lysimeters contained the following treatments: a typical soil cover acting as a baseline, a modified (EPA-RCRA) cover, and two versions of a LANL design using vegetation cover to enhance evapotranspiration and a capillary barrier to divert downward flow of water (Hakonson et al. 1993). Three of the lysimeters contained sloping layered soils designed to divert moisture horizontally. The fourth lysimeter, and the only one which will remain intact, is a soil overlaying compacted clay, representative of an EPA-RCRA cap. The location of the new lysimeter relative to the existing lysimeters is shown in Figure 3.2. The lysimeter area is shown in Figure 3.3 as it appeared in September 1993 as LANL staff were removing their equipment from the site.

The EPA-RCRA cap design consisted of $120 \mathrm{~cm}$ (47.3 in.) of topsoil over $30 \mathrm{~cm}$ (11.8 in.) of a sand drainage layer over $60 \mathrm{~cm}$ (23.6 in.) of a clay loam amended with bentonite and compacted to $1.76 \mathrm{~g} / \mathrm{cm}^{3}$. As reported in Hakonson et al. (1993), the saturated hydraulic conductivity of the clay layer was $3.4^{*} 10^{-6} \mathrm{~cm} / \mathrm{sec}$ (standard deviation $=1.81 * 10^{-6} \mathrm{~cm} / \mathrm{sec}$ ) rather than the EPA recommendation of $10^{-7} \mathrm{~cm} / \mathrm{sec}$. 



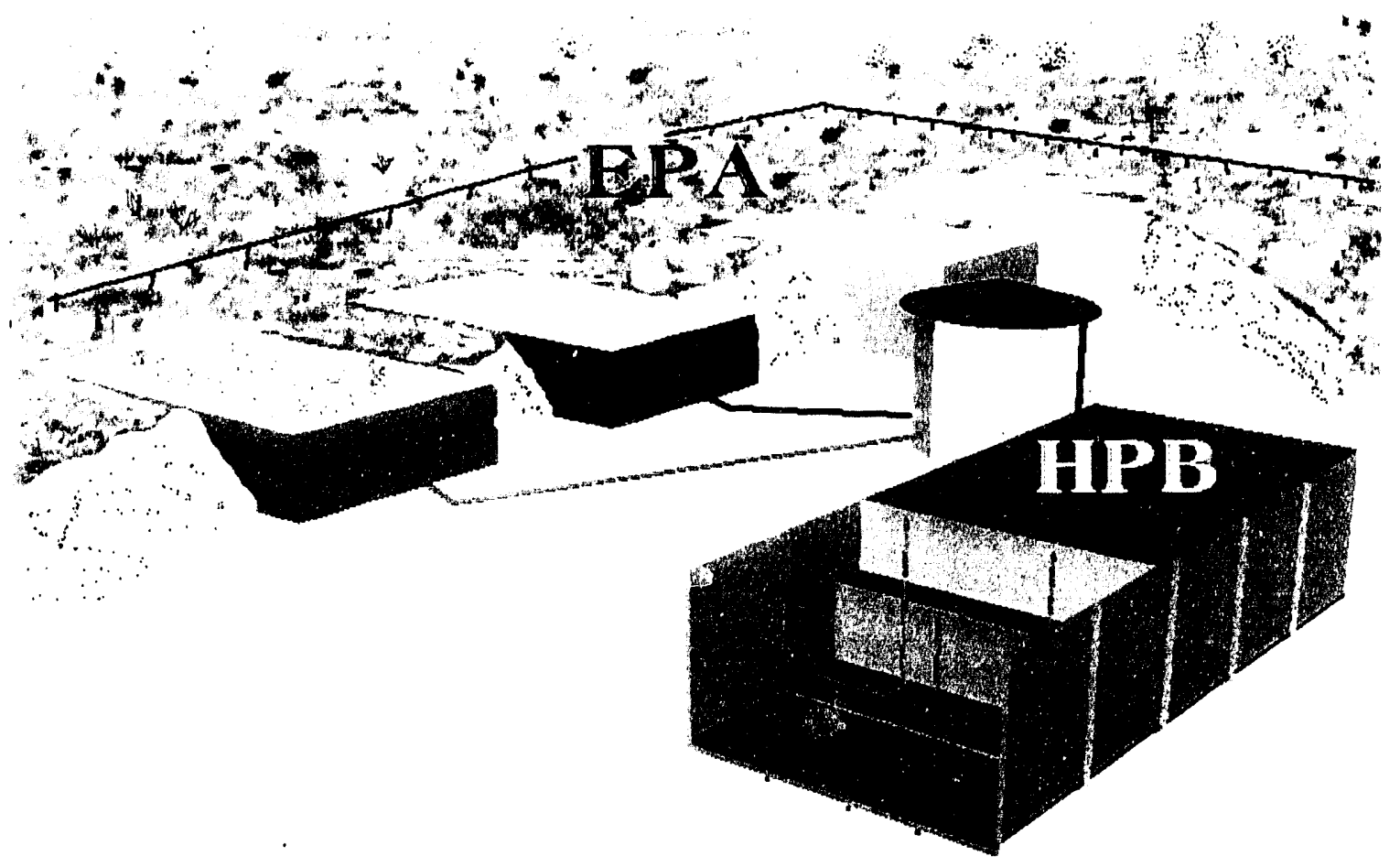

Figure 3.2. Perspective View of New Hanford Barrier Lysimeter (HPB) and Existing EPA-RCRA Lysimeters

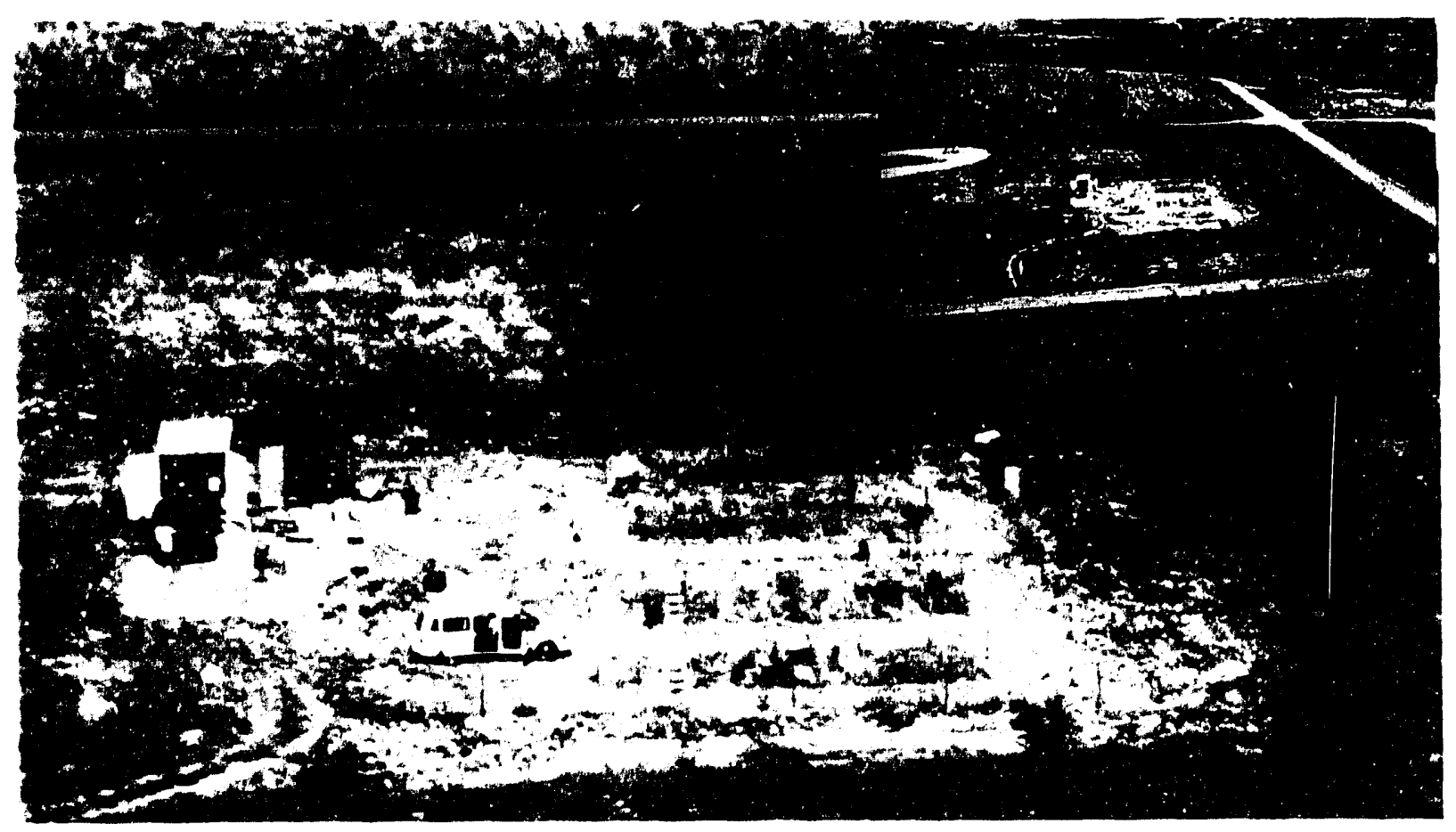

Figure 3.3. View of Hill AFB, Utah, Lysimeters, Looking North 


\subsection{Lysimeter Design}

The lysimeter will be constructed from L-shaped fiberglass sections bolted together in the field. This is essentially the same design used by LANL researchers at Hill AFB (Hakonson et al. 1993). There are two differences in the lysimeter design: 1) the new vendor-supplied fiberglass panels will create a 2.4-m-deep (8-ft-deep) lysimeter without the addition of extension panels, and 2) soil layers within the lysimeter will not have the $4 \%$ slope that was used in the LANL treatments. The bottom of the lysimeter will have two drainage collection areas created from $0.05-\mathrm{cm}(0.02-i n$.) reinforced geomembrane sheets laying on the lysimeter floor. The edges of the geomembrane sheet will be raised on the ends and down the center of the long axis by draping the sheei material over 15-cm (5.91-in.) PVC pipe. The geomembrane sheet is installed for two reasons: 1) because the side walls may act as preferential drainage pathways, flow down the side walls will be collected separately from the area over the geomembrane sheet, and 2) if the water table outside the lysimeter should rise above the floor of the lysimeter, and if unlikely seam failures occur, water entering the lysimeter would be collected as sidewall drainage and would not affect the primary drainage estimate obtained from the lysimeter area above the geomembrane sheet.

The dimensions and estimated volume of materials required are shown in Figure 4.1. The basic components of the lysimeter appear in the Hanford Protective Barrier lysimeter located in an exploded view of the lysimeter components and backfill layers in Figure 4.2. 


\section{Layer thickness}

$$
\begin{aligned}
& \text { siltloam1 }:=1 \cdot \mathbf{m} \quad \text { sand }:=.15 \cdot \mathbf{m} \quad \text { gravel_1 }:=.15 \cdot \mathbf{m} \\
& \text { siltloam2 }:=1 \cdot \mathbf{m} \\
& \text { gravel_2 }:=.15 \cdot \mathbf{m}
\end{aligned}
$$

siltloam1 + siltloam2 + sand + gravel_1 + gravel_2 $=2.4 \cdot \mathrm{m}$

Siltloam density

$$
\text { density }:=1.4 \cdot \frac{\mathrm{gm}}{\mathrm{cm}^{3}} \quad \text { density }=87.4 \cdot \frac{\mathrm{lb}}{\mathrm{ft}^{3}}
$$

\section{Lysimeter dimensions}

$$
\begin{aligned}
& \text { width }:=15 \cdot \mathrm{ft} \quad \text { length }:=36 \cdot \mathbf{f t} \quad \text { depth }:=8 \cdot \mathbf{f t} \\
& \text { width }=4.572 \cdot \mathrm{m} \quad \text { length }=10.973 \cdot \mathrm{m} \quad \text { depth }=2.438 \cdot \mathrm{m} \\
& \text { vol := width } \cdot \text { length } \cdot(\text { siltloam1 }+ \text { siltloam2 }) \\
& \text { vol }=3.543 \cdot 10^{3} \cdot \mathrm{ft}^{3} \quad \mathrm{vol}=131.2 \cdot \mathrm{yd}^{3} \quad \mathrm{vol}=100.3 \cdot \mathrm{m}^{3} \\
& \text { vol_1 }:=\text { width } \cdot \text { length } \cdot(\text { siltloam } 1) \\
& \text { gravel_vol :=vol_1 } 15 \cdot \% \\
& \text { gravel_vol }=9.843 \cdot \mathbf{y d}^{3} \\
& \text { Volume of silt loam needed at Hill AFB } \\
& \text { vol_silt }=\text { vol - gravel_vol } \\
& \text { vol_silt }=121.391 \cdot \mathrm{yd}^{3} \quad \text { vol_silt } \cdot \text { density }=143.228 \cdot \text { ton }
\end{aligned}
$$

Figure 4.1. MathCad File of Dimensions and Volume Calculations for Lysimeter Layers 


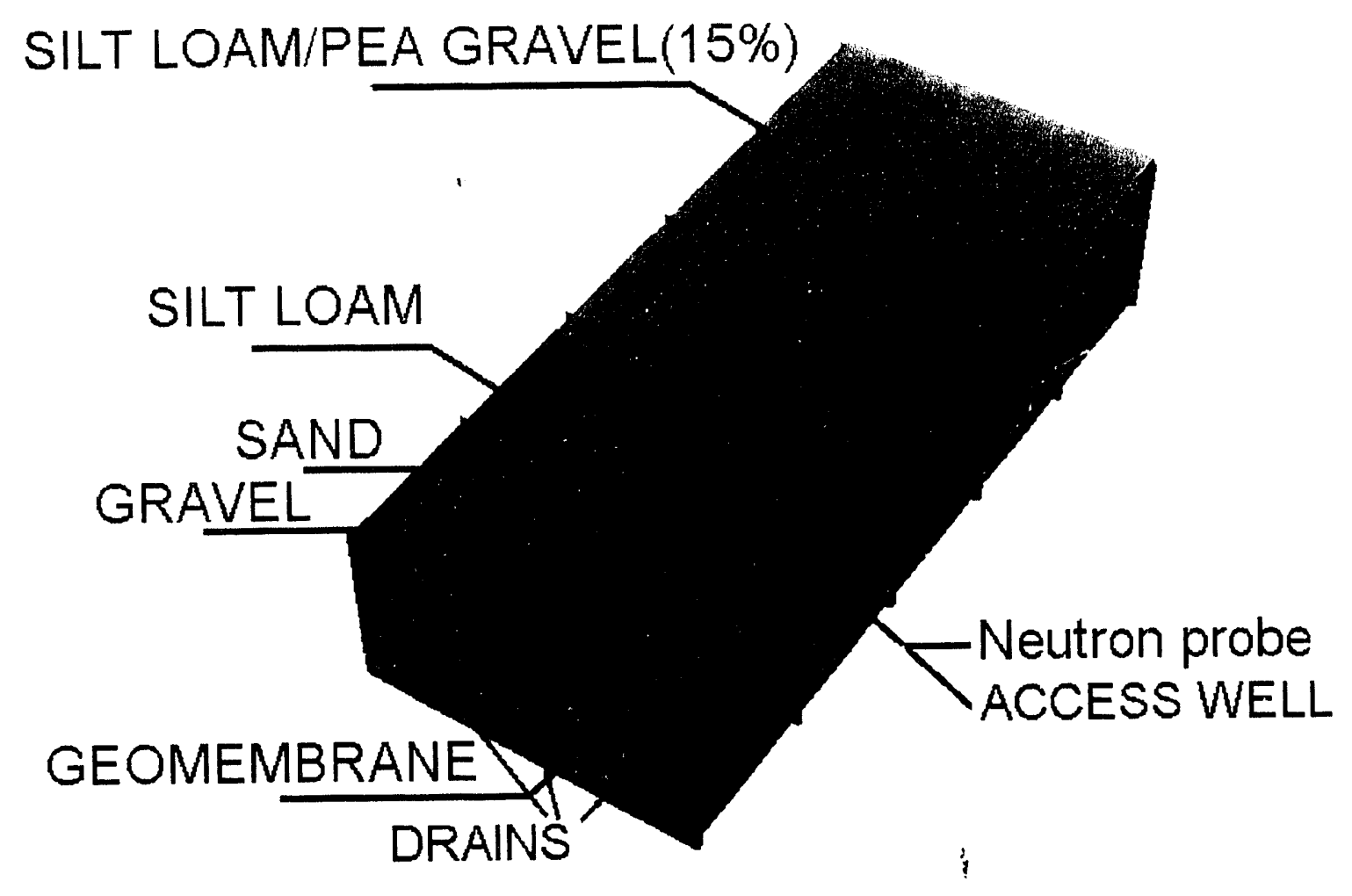

Figure 4.2. Lysimeter Layers (staggered cross-section) 


\subsection{Construction}

The objective of this construction is to create a lysimeter or control volume that limits water entry and exit to the soil surface and drain ports on the bottom. Horizontal flow is eliminated by the waterproof lysimeter walls. Water flux at the soil surface occurs as precipitation additions and evapotranspiration losses. If the soil profile allows sufficient water to percolate downward, bringing the soil layer at the soil-sand interface to near saturation, water will move into the underlying coarse materials. This water will reach the sloping geomembrane, move to the drain ports, and be measured in the existing instrument caisson.

The lysimeter is constructed from readily obtainable modular fiberglass swimming pool pieces. Construction is broken down into several steps and each step is described in the following section.

\subsection{Lysimeter Step-by-Step Construction}

Note: In this section, units are English, which is more common in construction drawings, followed by metric in parenthesis. A subset of the construction drawings is included in Figures 5.1 and 5.2. These drawings are provided for general overview of construction; they are not to scale and some details such as line thickness and type have been lost in the reduction.

\section{Do Site Survey}

A. Establish reference elevation point. Reference elevation may be taken from top (west end) of existing lysimeters at $4809.75 \mathrm{ft}$ (1466 m).

B. Stake excavation perimeter.

C. Flag location of existing drainage lines from eastern-most existing lysimeter as shown on drawing. Buried pipes are non-metallic. Any excavation near this area should be done by hand until pipes are located.

\section{Secure Backfill}

A. Silt loam soil

1. Excavate 200 tons $(181,400 \mathrm{~kg}$ ) of soil at Hanford (not part of contract)

2. Transport to Hill AFB (may be part of contract)

a. If by truck, stockpile next to excavation.

b. If by rail, store in rail car until needed (required capability).

(1) Propose method to empty car.

(2) Move soil to excavation site.

(3) Lay 10-mil (0.254-mm) plastic sheet to dump soil on.

B. Mix $65 \mathrm{yd}^{3}\left(49.7 \mathrm{~m}^{3}\right)$ of silt loam with $7 \mathrm{yd}^{3}\left(5.3 \mathrm{~m}^{3}\right)$ pea gravel to achieve $15 \%$ by weight of pea gravel to be used as final $3.28-\mathrm{ft}(1-\mathrm{m})$ layer.

1. Method one: transport $65 \mathrm{yd}^{3}\left(49.7 \mathrm{~m}^{3}\right)$ of soil to pug mill and mix with $7 \mathrm{yd}^{3}$ $\left(5.3 \mathrm{~m}^{3}\right)$ pea gravel, then transport mix to site and store on 10 -mil plastic sheet.

2. Method two: make temporary mixing pad from several $4 \times 8 \mathrm{ft}(1.22 \times 2.44 \mathrm{~m})$ sheets of plywood, mix soil on the temporary pad during construction by alternating layers of soil and pea gravel, then rototill, and stockpile as above. 


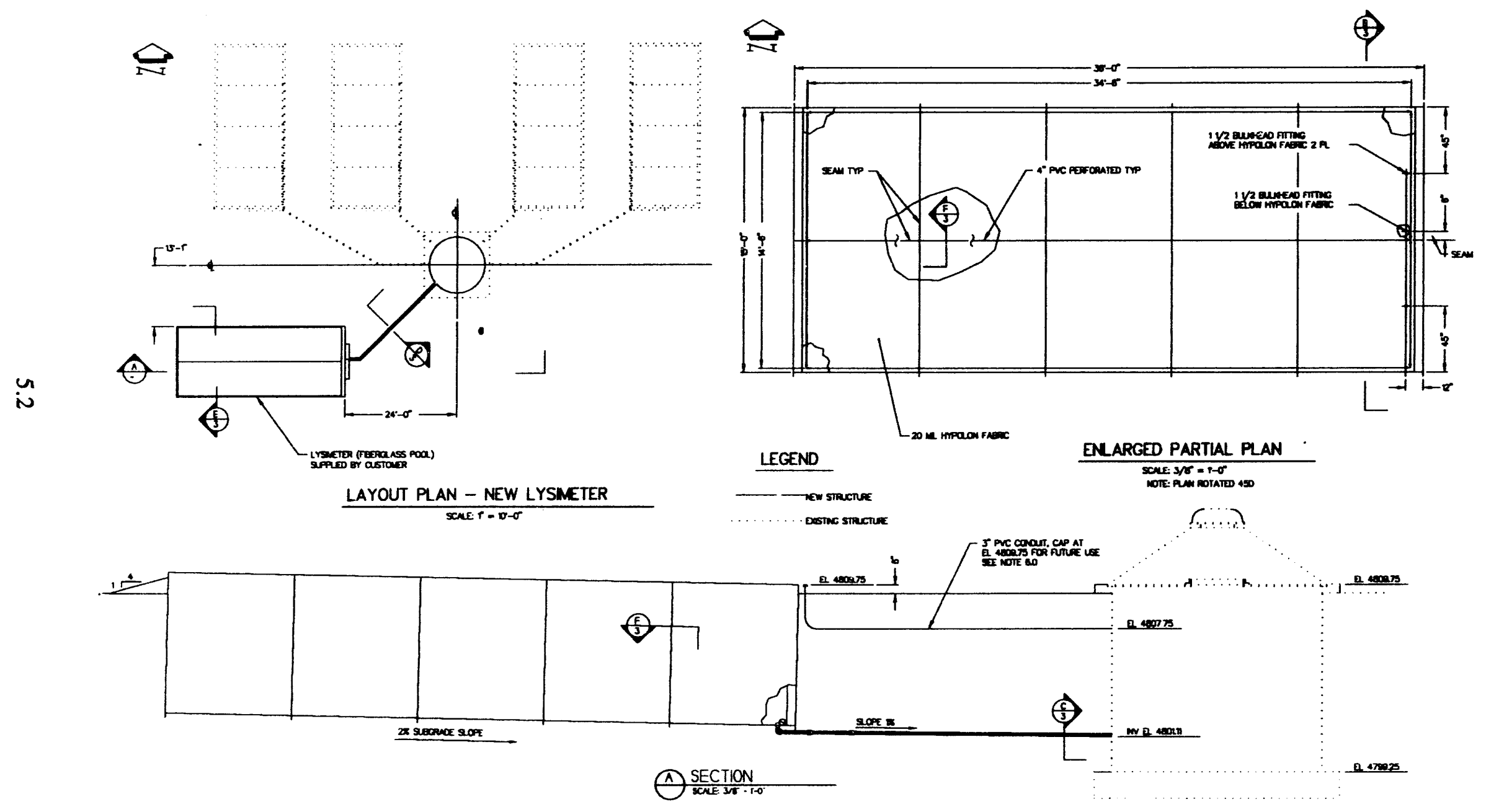

Figure 5.1. Plan View of Lysimeter Construction Drawings 

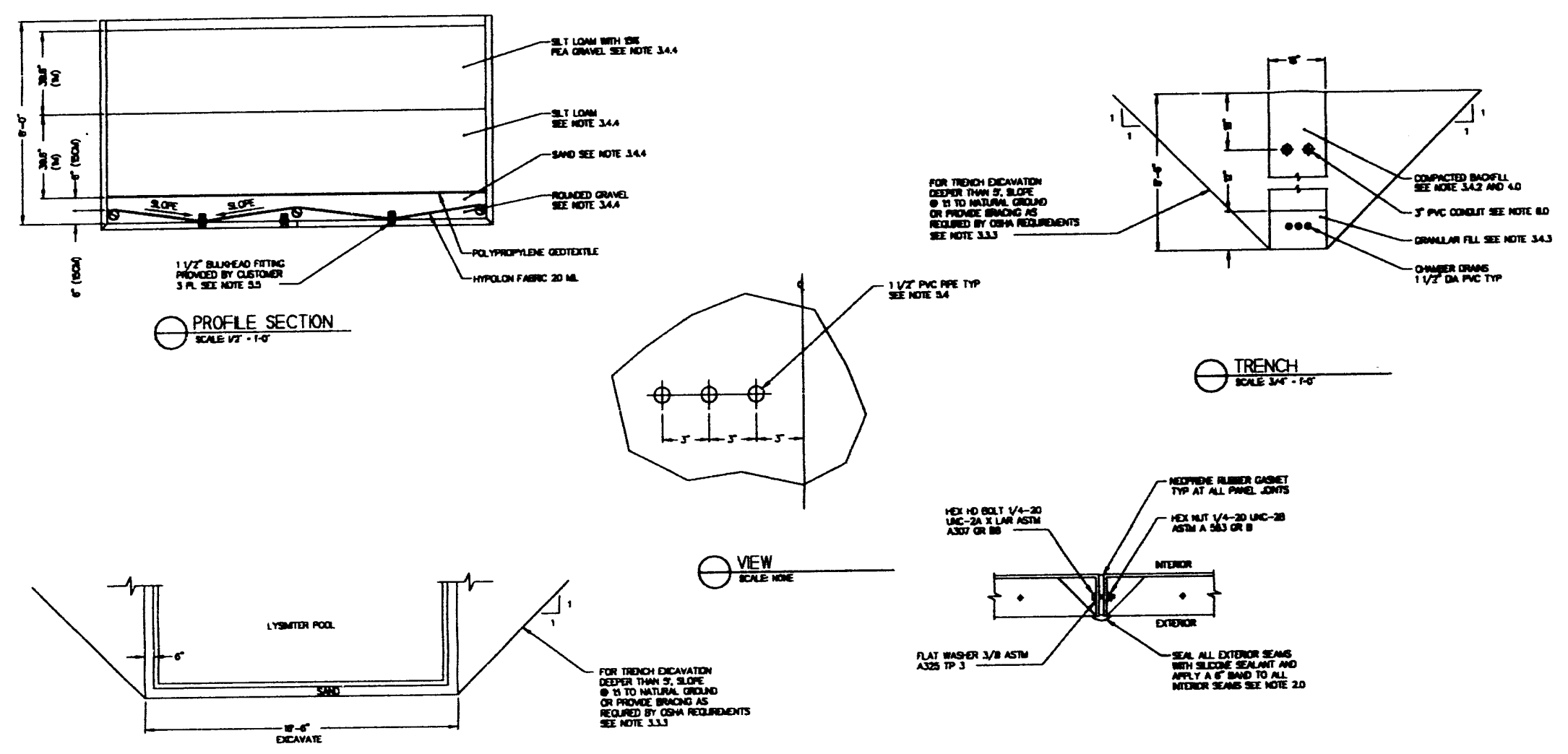

$\Theta_{\text {SECTION TYP }}^{\text {SWA }}$

OXCAVATION SECTION

Figure 5.2. Elevation View of Lysimeter Construction Drawings 

C. Local sandy soil
1. Screen excavation material for use as backfill outside lysimeter.
2. Purchase locally.
D. Add water to soil for optimum compaction.

III. Excavate Soil for Lysimeter Pit and Drainage Pipe Trench to Instrument Caisson

A. Maintain 1:1 slope on side walls on all trenches deeper than $5 \mathrm{ft}(1.5 \mathrm{~m})$.

B. Follow all applicable Hill AFB construction safety rules for pit excavations.

C. Stockpile screened backfill material.

IV. Cut Access Holes
A. Cut three 1.5 -in. $(3.8-\mathrm{cm})$ holes in steel caisson wall at approximately $8.5 \mathrm{ft}(2.6 \mathrm{~m})$ below grade and a minimum of $0.5 \mathrm{ft}(15 \mathrm{~cm})$ below lowest point of new lysimeter.

\section{Prepare Excavation Floor}

A. Prepare 6-in. (15-cm) sandy bed to set pool structure on. Leave space for drain pipes.

VI. Construct Lysimeter/Tank by Bolting Together L-shaped Sections
A. The contractor will provide a support mechanism capable of supporting the lysimeter L-shaped pieces a minimum of $5 \mathrm{ft}(1.5 \mathrm{~m})$ above the bottom of the excavation during the time the pieces are being bolted together. Total weight supported will be less than $2000 \mathrm{lb}$ (907 kg).
B. Join each section on the flange edge to the adjacent section by 0.25 -in. $(0.63-\mathrm{cm})$ bolts spaced approximately 6 in. $(15 \mathrm{~cm})$ apart. Insert a compressible foam membrane strip (supplied) between each section as it is bolted together, forming a water-tight seal.

C. Apply silicone rubber coating to all exterior seams.
D. Repair any damage to the lysimeter, first with a fiberglass patch, then with a silicone rubber coating.
E. Attach three supplied drain fixtures; prepare ends for later addition of 1.5-in. (3.8-cm) PVC fittings.

\section{Lower the Lysimeter}
A. Create depressions in sand layer for lysimeter seams.
B. (Optional) Leave steel cross-member support used in elevated scaffolding under lysimeter.

\section{Seal Seams}
A. Apply silicon rubber in 6-in. (15-cm) band to all seams.

\section{Connect Drains}
A. Attach 90-degree elbows to drains.
B. Connect three 1.5-in. (3.8-cm) PVC pipes between drains and instrument caisson.

\section{Check Slope}
A. Contractor will confirm bottom slope of lysimeter.
B. Pacific Northwest Laboratory (PNL) researchers will confirm 4-degree slope of lysimeter with survey equipment or water level.




\section{Inspect Interior}

A. Walk the interior of the pool to determine poorly backfilled areas and repack backfill under floor of lysimeter by tamping from the sides.

XII. Do Leak Test

A. Add $1 \mathrm{ft}$ depth (4039 gal) of water to lysimeter, PNL staff will place pressure gauge capable of $1 / 1000-\mathrm{ft}$ accuracy in drain end. Cover lysimeter with plastic sheet (10-mil minimum), leave tank for 2-day leak test.

B. Remove leak test water.

XIII. Inspect Interior

A. Do second walk of interior of the pool to determine poorly backfilled areas.

B. Re-pack backfill under floor of lysimeter if necessary.

XIV. Prepare Footing (Optionen

A. Prepare shallow forms for $1-\mathrm{ft}(30-\mathrm{cm})$ non-reinforced concrete pour around base of lysimeter extending 2 feet out from pool and 1 foot up the outside of the pool. It is not necessary for cement to extend under lysimeter.

XV. Create Floor Level Drainage Impoundments Collection

A. Place three 35- $\mathrm{ft}(10.6-\mathrm{m})$ of 3 in. $(15 \mathrm{~cm}) \mathrm{PVC}$ drain field pipe (joined short pieces allowable) along the edges and down the center (long axis) connect with two 14.5- $\mathrm{ft}$ $(4.42-\mathrm{m})$ pieces along the ends (short axis) using elbows or tees as needed. This pipe facilitates horizontal drainage down the long axis and elevates the edge of the geomembrane liner (to separate wall effect drainage from the central lysimeter area).

B. Place rounded gravel (1/4 to $3 / 4$ in., not crushed) adjacent to $3-i n$. $(15-\mathrm{cm})$ PVC pipe to provide sloping surface toward the lengthwise center-line of each sampling rectangle formed by the PVC pipe.

C. Drape $15-$ by $36-\mathrm{ft}(4.57-$ by $10.97-\mathrm{m}) 20$-mil geomembrane over the PVC frame and gravel floor. This acts to divide the lysimeter lengthwise into two drainage collection areas, and separate sidewall drainage from the central areas of the lysimeter.

XVI. Connect Drains

A. Screw hollow drain bolt into 1.5 -in. $(3.8-\mathrm{cm})$ bulkhead fitting, clamping geomembrane liner to bulkhead fitting. Repeat on the other half of lysimeter [(bulkhead located $1 / 4$ of the width from each side and $1 \mathrm{ft}(30 \mathrm{~cm})$ from the end of the lysimeter)]. These two drainage pipes extend to the instrument caisson and provide the primary measurement of drainage from the lysimeter.

B. Connect third 1.5-in. $(3.8-\mathrm{cm})$ recessed bulkhead located near center of the lysimeter and $1 \mathrm{ft}(30 \mathrm{~cm})$ from the end to the PVC pipe running to the instrument lysimeter; this pipe collects all side wall drainage.

XVII. Leak Test all Hose/Pipe Connections

A. Pressure check drain hoses with air pressure.

B. Check drainage surface of geomembrane by spraying water and looking for ponded water.

C. Adjust gravel under geomembrane to eliminate ponding. 


\section{Place Coarse Layers}

A. Place 6-in. (15-cm) rounded gravel backfill using bucket of track-hoe to lower material into lysimeter level gravel surface.

B. Place 6-in. $(15-\mathrm{cm})$ clean sand layer on top of gravel.

C. Place a geotextile over the top of the sand layer; use a non-woven, needle-punched polypropylene geotextile (to be supplied).

XIX. Place First Meter of Soil

A. Place four 7.8 -in. $(20-\mathrm{cm})$ lifts of Warden silt loam soil into the lysimeter. The fifth lift will be $7.8 \mathrm{in} .(20 \mathrm{~cm})$ plus any needed to bring the total thickness to $39.4 \mathrm{in}$. $(1 \mathrm{~m})$ after compaction. Level and compact each lift to a bulk density of 1.3 to $1.5 \mathrm{~g} / \mathrm{cm}^{3}$ (little additional compaction after leveling is expected). The layer will be checked for density and soil water content by PNL research staff. The outside of the lysimeter will be backfilled to the current interior soil level after each soil lift addition and before interior compaction. The outside backfill will also be compacted after at least every other lift. Instrumentation may be placed into soil layers by PNL staff with all wiring taped to the side of the lysimeter to minimize impact upon construction activities.

\section{Place Second Meter of Soil}

A. Place 6 in. $(15 \mathrm{~cm})$ lifts of Warden silt loam soil mixed with $15 \%$ by weight pea gravel. After spreading, leveling, and compacting each lift to a bulk density of 1.3 to $1.5 \mathrm{~g} / \mathrm{cm}^{3}$, the layer will be checked for density and soil water content by PNL research staff. Add additional 6-in. (15-cm) lifts, pausing for density and moisture checks after each lift addition. The outside of the lysimeter will be backfilled and compacted to the current interior soil level after each soil lift addition.

B. (MIX IN PLACE OPTION) Place 6-in. (15-cm) lifts of Warden silt loam soil and 2- to 3$\mathrm{cm}$ pea gravel together. Then thoroughly mix by rototilling gravel into the soil layer, level and compact each lift to a bulk density of 1.3 to $1.5 \mathrm{~g} / \mathrm{cm}^{3}$. The layer will be checked for density and soil water content by PNL research staff. Add additional 6-in. $(15-\mathrm{cm})$ siltloam and 2-cm pea gravel lifts, mix each layer, and complete density and moisture checks after each lift addition. The outside of the lysimeter will be backfilled and compacted to the current interior soil level after each soil lift addition.

XXI. Backfill and Cleanup

A. Backfill and grade area surrounding lysimeter.

B. Remove and dispose of construction waste materials.

C. END CONTRACT WORK.

\section{Revegetate and Install Instruments}

A. Pacific Northwest Laboratory researchers will transplant sagebrush and selected bunch grasses on the lysimeter. The lysimeter will be irrigated weekly until the total soil moisture profile is similar to the EPA-RCRA lysimeter. Neutron or capacitance probe access wells will be installed into the soil layers. 


\subsection{Measurement Program}

The measurement program is intended to continue for 3 years. During this time, data will be collected from both automated and manually read instrumentation. Descriptive plant measurements will be taken at least quarterly and used as input for vegetation parameters in model simulations. Soil properties will be measured during construction and at yearly intervals. Similar to the vegetation data, these values are needed for initiation of soil parameters in the model validation effort which is a separate surface barrier technology task.

\subsection{Instrumentation}

Similar to the prototype barrier test at Hanford, the primary measurement will be the collection and quantification of drainage water passing through the barrier. All data collection will adhere to the principles outline in the PNL document QA Plan for PNL Support for the Hanford Barriers

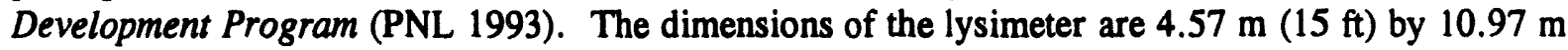
(36 ft). If $0.5 \mathrm{~mm}$ of water (barrier design criterion) moves through the barrier, $25.08 \mathrm{~L}(6.62 \mathrm{gal})$ of water would be collected. Expected resolution and precision of monitoring instrumentation are presented in Table 6.1.

Because little water is expected to pass through the barrier, changes in stored soil moisture will also be measured. Soil moisture measurements will be made at a minimum of six depths at six locations on the lysimeter using either a neutron or a capacitance moisture probe. Near-surface soil samples (0-1 and 0-5 cm depths) will be collected for gravimetric moisture determination each time the soil profile moisture is measured with either moisture probe. A graduate student from Utah State University (Logan, Utah) will assist in this investigation. Additional soil water content measurements may be made using time-domain reflectometry. In addition, transpiration may be measured using stem flow gauges on the transplanted sagebrush.

Precipitation will be measured using a standard tipping bucket gauge, collection rain gauges, and a weighing rain gauge, which provides a more temporally correct measurement of snowfall and snow cover sublimation. Wind speed and direction will be measured at the $2-\mathrm{m}(6.56-\mathrm{ft})$ elevation. Net radiation, air temperature, and relative humidity will also be measured. 
Table 6.1. Instrumentation Measurement Capabilities

\begin{tabular}{|c|c|c|c|c|}
\hline Component & $\begin{array}{l}\text { Measurement } \\
\text { Method }\end{array}$ & $\begin{array}{l}\text { Instrument } \\
\text { Resolution }\end{array}$ & $\begin{array}{l}\text { Expected } \\
\text { Precision }\end{array}$ & $\begin{array}{l}\text { Variability } \\
\text { Estimates }\end{array}$ \\
\hline Drainage & $\begin{array}{l}\text { Weight outflow } \\
\text { water }\end{array}$ & $\begin{array}{l} \pm 1.0 \mathrm{~g} \\
\text { top-loading scale }\end{array}$ & $1.0 \mathrm{~g}$ & not applicable \\
\hline \multirow[t]{3}{*}{ Storage change } & \multirow[t]{2}{*}{ Neutron probe } & \multirow[t]{2}{*}{$0.005 \mathrm{~cm}^{3} / \mathrm{cm}^{3}$} & $\begin{array}{l}\text { absolute } \\
0.01 \mathrm{~cm}^{3} / \mathrm{cm}^{3} \\
\text { times } 200 \mathrm{~cm}= \\
2 \mathrm{~cm}\end{array}$ & \\
\hline & & & $\begin{array}{l}\text { relative } \\
\sigma_{x=}=\sigma / \int 60 \\
0.0013 * 200 \mathrm{~cm} \\
=0.25 \mathrm{~cm}^{(\mathrm{a})}\end{array}$ & \\
\hline & Capacitance & $0.01 \mathrm{~cm}^{3} / \mathrm{cm}^{3}$ & & \\
\hline \multirow[t]{2}{*}{ Rain gage } & $\begin{array}{l}\text { non-heated } \\
\text { tipping bucket }\end{array}$ & $0.25 \mathrm{~mm}$ & $0.25 \mathrm{~mm}$ & $\begin{array}{l}0.1 \mathrm{~cm} \text { wind } \\
\text { effects and up to } \\
1 \mathrm{~cm} \text { for snow }\end{array}$ \\
\hline & weighing gage & $0.1 \mathrm{~mm}$ & $\begin{array}{l}0.5 \mathrm{~mm} \\
\text { temperature } \\
\text { sensitive }\end{array}$ & $0.05 \mathrm{~cm}$ wind \\
\hline Net radiation & $\begin{array}{l}\text { differential } \\
\text { black body }\end{array}$ & $0.1 \mathrm{~W} / \mathrm{m}^{2}$ & $1 \mathrm{~W} / \mathrm{m}^{2}$ & up to $40 \mathrm{~W} / \mathrm{m}^{2}$ \\
\hline Soil Heat Flux & thermopile & $0.1 \mathrm{~W} / \mathrm{m}^{2}$ & $1 \mathrm{~W} / \mathrm{m}^{2}$ & up to $30 \mathrm{~W} / \mathrm{m}^{2}$ \\
\hline Temperature & thermocouple & $0.01^{\circ} \mathrm{C}$ & $0.1^{\circ} \mathrm{C}$ & up to $2^{\circ} \mathrm{C}$ \\
\hline snow depth & $\begin{array}{l}\text { sonic distance } \\
\text { gage }\end{array}$ & $1 \mathrm{~mm}$ & $10 \mathrm{~mm}$ & $\begin{array}{l}\text { up to } 150 \mathrm{~mm} \\
\text { with drifts }\end{array}$ \\
\hline anemometer & $\begin{array}{l}\text { cup anemometer } \\
\text { with magnetic } \\
\text { switch closure }\end{array}$ & $\begin{array}{l}0.8 \mathrm{~km} / \mathrm{hr} \\
\text { threshold }\end{array}$ & $0.8 \mathrm{~km} / \mathrm{hr}$ & $\begin{array}{l}0.8 \mathrm{~km} / \mathrm{hr} \text { at } \\
\text { twice the height } \\
\text { of the canopy }\end{array}$ \\
\hline \multicolumn{5}{|c|}{$\begin{array}{l}\text { Variability estimates are given for sparse canopies and are based on authors' experience. } \\
\text { These values are usually greatly reduced by judicial sensor positioning or multiple sensors. } \\
\text { (a) Assume standard deviation of neutron probe readings is } .01 \mathrm{~cm}^{3} / \mathrm{cm}^{3} \text {, six sampling wells } \\
\text { with ten measurements in each well. }\end{array}$} \\
\hline
\end{tabular}




\subsection{Data Base}

All data collected from this site will be recorded in official project notebooks or on magnetic media. Field observation will be recorded in PNL laboratory notebooks or water-proof field notebooks if necessary. Data collected using Campbell Scientific Inc. data loggers will be directly communicated to PNL-Richland through phone lines. These data loggers will also have tape backup recorders in the field. Other data recording devices may be used intermittently; data from these devices will be transmitted to PNL via 3 1/2" IBM floppy disks.

Devices, such as the neutron moisture probe, which have several seconds of operator idle time during each measurement should have a manual field notebook entry and a memory dump to floppy disk, with copies or originals returned to PNL. Blank data sheets will be used for repetitive measurements to minimize errors. These data sheets will then be taped into PNL record books.

The field site will documented with both 8-mm HI-Band video and 35-mm still photography. Fixed reference picture points will be established and select images will be digitized and provided for vegetation measurement and general documentation of the site.

\subsection{Quality Assurance}

Pacific Northwest Laboratory has collaborated with Westinghouse Hanford Company in developing the present quality assurance plan (PNL 1983) for the project Surface Barrier Technology. The Hill AFB lysimeter addition is task 6.0 of this project and the quality assurance guidelines set forth in the quality assurance plan will be followed. Foremost for this project are the documentation of actual construction and instrument placement, the maintenance of instrument calibration records, and because of the remote site location, a redundant measurement program with multiple measurement methods. 


\subsection{References}

DOE (U.S. Department of Energy). 1987. Final Environmental Impact Statement, Disposal of Hanford Defense High Level, Transuranic and Tank Wastes at Hanford Site. Vol. 1, DOE/EIS-0113, U.S. Department of Energy, Washington, D.C.

DOE (U.S. Department of Energy). 1993. Report on Value Engineering Study of Permanent Isolation Surface Barriers and Warning Marker System Development Plan at the Hanford Site. DOE-RL-12074-8, Rev. 0., U.S. Department of Energy, Washington, D.C.

Gee, G. W., D. G. Felmy, J. C. Ritter, M. D. Campbell, J. L.Downs, M. J.Fayer, R. R. Kirkham, and S. O. Link. 1993a. Field Lysimeter Test Facility Status Report IV, FY1993. PNL-8911, Pacific Northwest Laboratory, Richland, Washington.

Gee, G. W., L. L. Cadwell, H. D. Freeman, M. W. Ligotke, S. O. Link, R. A. Romine, W. H. Walters, Jr. 1993b. Testing and Monitoring Plan for the Permanent Isolation Surface Barrier Prototype. PNL-8391, Pacific Northwest Laboratory, Richland, Washington.

Hakonson, T. E., K. L. Manies, R. W. Warren, K. V. Bostick, G. Trujillo, J. S. Kent, and L. J. Lane. 1993. "Migration Barrier Covers for Radioactive and Mixed Waste Landfills." In: The Proceedings of the Second Environmental Restoration Technology Transfer Symposium, San Antonio, Texas.

PNL (Pacific Northwest Laboratory). 1993. PNL-MA-70 Quality Assurance Plan. No. OHE-002, Rev 4, Pacific Northwest Laboratory, Richland, Washington.

Wing, N. R. 1994. Permanent Isolation Surface Barrier Development Plan. WHC-EP-0673, Westinghouse Hanford Company, Richland, Washington. 


\section{Distribution}

No. of

Copies

OFFSITE

12 DOE/Office of Scientific and Technical Information

C. S. Abrams

Argonne National Laboratory

P.O. Box 2528

Idaho Falls, ID 83401

3 Battelle Memorial Institute

Project Management Division

505 King Avenue

Columbus, $\mathrm{OH} 43201$

ATTN: W. A. Carbeiner

W. S. Madia

Technical Library

M. Benge

Bechtel-FUSRAP

P.O. Box 350

Oak Ridge, TN 37830

R. D. Bennett

U.S. Army Engineer Waterways

Experiment Station

3909 Halls Ferry Road

Vicksburg, MS 39180-6199

B. Bede

US Ecology

509 E. 12th

Olympia, WA 98501
No. of

Copies

OFFSITE

4 Chem Nuclear Geotech

P.O. Box 14000

Grand Junction, CO 81502

ATTN: J. Duray

J. Elmer

V. Ponc

W. J. Waugh

A. T. Clark

U.S. Nuclear Regulatory Commission

Division of Fuel Material Safety

Washington, D.C. 20555

D. E. Daniel

University of Texas

Dept. of Civil Eng.

Austin, TX 78712

2 Desert Research Institute

P.O. Box 60220

Reno, NV 89506

ATTN: J. T. Ball

S. W. Tyler

M. Dunkelman

Department of Health

Division of Radiation

Protection

Airdustrial Park

Bldg. 5, M.S. LE-13

Olympia, WA 98504

EBASCO

1201 Jadwin

Richland, WA 99352

ATTN: R. L. Treat

Distr.1 
No. of

Copies

\section{OFFSITE}

2 Environmental Protection Agency

Hanford Project Office

712 Swift, MS B5-01

Richland, WA 99352

ATTN: D. A. Faulk

P. S. Innis

\section{S. Evans}

U.S. Department of Energy

1580 Sawtelle Drive

Idaho Falls, ID 83403

3 Hill Air Force Base

Environmental Management

Directorate

OO-ALC/EM*

7276 Wardleigh Road

Hill AFB, UT 84056-5127

ATTN: M. Blood

B. Elliot

D. Stone

R. G. Hills

Department of Mechanical Eng.

New Mexico State University

Box 30001

La Cruces, NM 88003

2 Idaho National Engineering

Laboratory

P.O. Box 1625

Idaho Falls, ID 83415

ATTN: J. B. Sisson Technical Library

Jacobs Engineering Group, Inc. 2155 Louisiana Blvd. NE \#10000 Albuquerque, NM 87110-5414

ATTN: T. Goering
No. of

Conies

\section{OFFSITE}

T. L. Jones

New Mexico State University

Agricultural Experiment Station

Box 3BF

Las Cruces, NM 88003

M. R. Jugan

U.S. Department of Energy

Oak Ridge Operations Office

P.O. Box E

Oak Ridge, TN 37830

'N. A. Jury

University of California

at Riverside

Dept. of Soils

Riverside, CA 92502

5 Los Alamos National Laboratory

P.O. Box 1663

Los Alamos, NM 87545

ATTN: F. Barnes

K. V. Bostick

T. E. Hakonson

J. W. Nyhan

E. Springer

E. Maestas

U.S. Department of Energy

West Valley Project Office

P.O. Box 191

West Valley, NY 14171

C. Massimino

U.S. Environmental Protection

Agency

1200 Sixth Avenue

Seattle, WA 98101

Distr.2 
No. of

Copies

OFFSITE

S. Needler

EG\&G, Rock Flats

P.O. Box 464, Building 080

Golden, CO 80402

2 Oak Ridge National Laboratory

P.O. Box Y

Oak Ridge, TN 37830

ATTN: W. D. Burch

R. J. Luxmoore

G. Page

USDA-ARS

2000 East Allen Rd.

Tucson, AZ 85719

J. Rensel, MS PV-11

Washington State Department of Ecology

High-Level Waste Management

Olympia, WA 98504

2 Sandia National Laboratories

P.O. Box 5800

Albuquerque, NM 87185

ATTN: R. W. Lunch

Technical Library

\section{J. B. Stong}

Gonzaga University

Civil Engineering Dept

E. 502 Boone

Spokane, WA 99258-0001

2 U.S. Department of Energy-

Albuquerque Operations Office

P.O. Box 5400, MS ERPO

Albuquerque, NM 87185-5400

ATTN: K. Bitner

G. J. Rael
No. of

Copies

\section{OFFSITE}

$3 \quad$ U.S. Department of Energy

785 DOE Place

Idaho Falls, ID 83402

ATTN: O. D. Markham

R. C. Morris

T. E. Reynolds

$2 \quad$ U.S. Department of Energy

Savannah River Operations

Office

P.O. Box A

Aiken, SC 29801

ATTN: W. J. Brumley

D. Bruegennjohann

2 U.S. Geological Survey $333 \mathrm{~W}$. Nye Lane

Carson City, NV 89706

ATTN: B. J. Andraski

D. E. Prudic

3 U.S. Geological Survey

Low-Level Radioactive Waste

Program

Water Resources Division 12201 Sunrise Valley Drive

Reston, VA 22092

ATTN: P. Stevens

N. Trask

1. Winograd

2 U.S. Geological Survey 1201 Pacific Ave., Suite 600 Tacoma, WA 98402

ATTN: W. R. Bidlake

B. W. Drost

Distr. 3 
No. of

Copies

\section{OFFSITE}

3 U.S. Nuclear Regulatory Commission

Division of Engineering Safety Waste Management Branch 5650 Nicholson Lane Rockville, MD 29852

ATTN: T. J. Nicholson

E. O'Donnell

M. Silberberg

2 Washington State Department of Ecology

$7601 \mathrm{~W}$. Clearwater, Suite 102

Kennewick, WA 99336

ATTN: D. Teal

N. Uziemblo

3 Washington State Department of Ecology

Mail Stop PV-11

Olympia, WA 98504-8711

ATTN: E. M. Carlin

C. Cline

R. B. Hibbard

Washington State University

Pullman, WA 99164

ATTN: G. S. Campbell

E. P. Weeks

U.S. Geological Survey

Federal Center Mail Stop 413

Denver, CO 80225

M. Weishan

NYSERDA

P.O. Box 191

West Valley, NY 14171
No. of

Copies

\section{OFFSITE}

Westinghouse Savannah River Company

P.O. Box 616

Aiken, SC 29802

ATTN: M. D. Boersma

P. J. Wierenga

University of Arizona

Dept. of Soil \& Water

429 Shantz Building

Tucson, AZ 85721

\section{ONSITE}

11 DOE Richland Operations Office
G. J. Bracken
A4-02
J. J. Broderick
A7-27
R. D. Freeberg
A5-19
R. E. Gerton
A4-02
J. D. Goodenough
A5-19
A. C. Harris
A5-19
R. D. Izatt
A3-42
P. M. Pak
A5-19
R. K. Stewart
A5-19
D. E. Trader
A5-90

DOR-RL Reading Room 1

$2 \quad$ U.S. Army Corps of Engineers

W. L. Greenwald

J. H. Jacobson

A5-20

A3-61

$4 \quad$ Kaiser Engineers Hanford Company

S. D. Consort

E6-31

D. L. Fort

E6-50

L. A. Gladdis

E6-50

R. I. Watkins

E6-41

Distr.4 
No. of

Copies

\section{ONSITE}

41 Westinghouse Hanford Company

M. R. Adams

H6-01

H. Babad

R2-78

R. J. Bliss

B3-04

M. A. Buckmaster

J. W. Cammann

R. A. Carlson

C. C. Chamberlain

A. P. Church

H. D. Downey

W. F. Heine

C. E. Hodge

R. W. Hookfin

G. W. Jackson

K. N. Jordan

C. J. Kemp

M. K. Korenko

D. S. Landeen

M. J. Lauterbach

R. E. Lerch

H. E. McGuire

D. R. Myers

D. J. Newland

K. L. Petersen

R. W. Powell

R. C. Roos

M. R. Sackschewsky

W. A. Skelly

J. C. Sonnichsen

J. A. Voogd

G. F. Williamson

N. R. Wing

T. M. Wintczak

D. D. (Don) Wodrich

R. D. Wojtasek

D. E. Wood

J. G. Woolard

Publishing Services (3)

Environmental Data Management

Center (2)
No. of

Copies

\section{ONSITE}

$38 \quad$ Pacific Northwest Laboratory

L. L. Cadwell P7-54

M. D. Campbell K6-77

J. L. Downs P7-54

M. J. Fayer K6-77

D. Felmy K6-77

M. G. Foley K6-84

H. D. Freeman P8-38

G. W. Gee K6-77

M. J. Graham K6-78

P. C. Hays K6-86

C. T. Kincaid K6-77

R. R. Kirkham (7) K6-77

G. V. Last K6-84

M. W. Ligotke P7-54

S. O. Link P7-54

E. Nyberg P7-72

T. L. Page K1-37

G. P. O'Connor K6-62

J. C. Ritter K6-77

M. L. Rockhold K6-77

L. E. Rogers P7-54

R. A. Romine P8-38

M. A. Simmons P7-54

M. E. Thiede K6-13

J. M. Thomas P7-54

W. H. Walters K6-06

Publishing Coordination

Technical Report Files (5)

Distr.5 

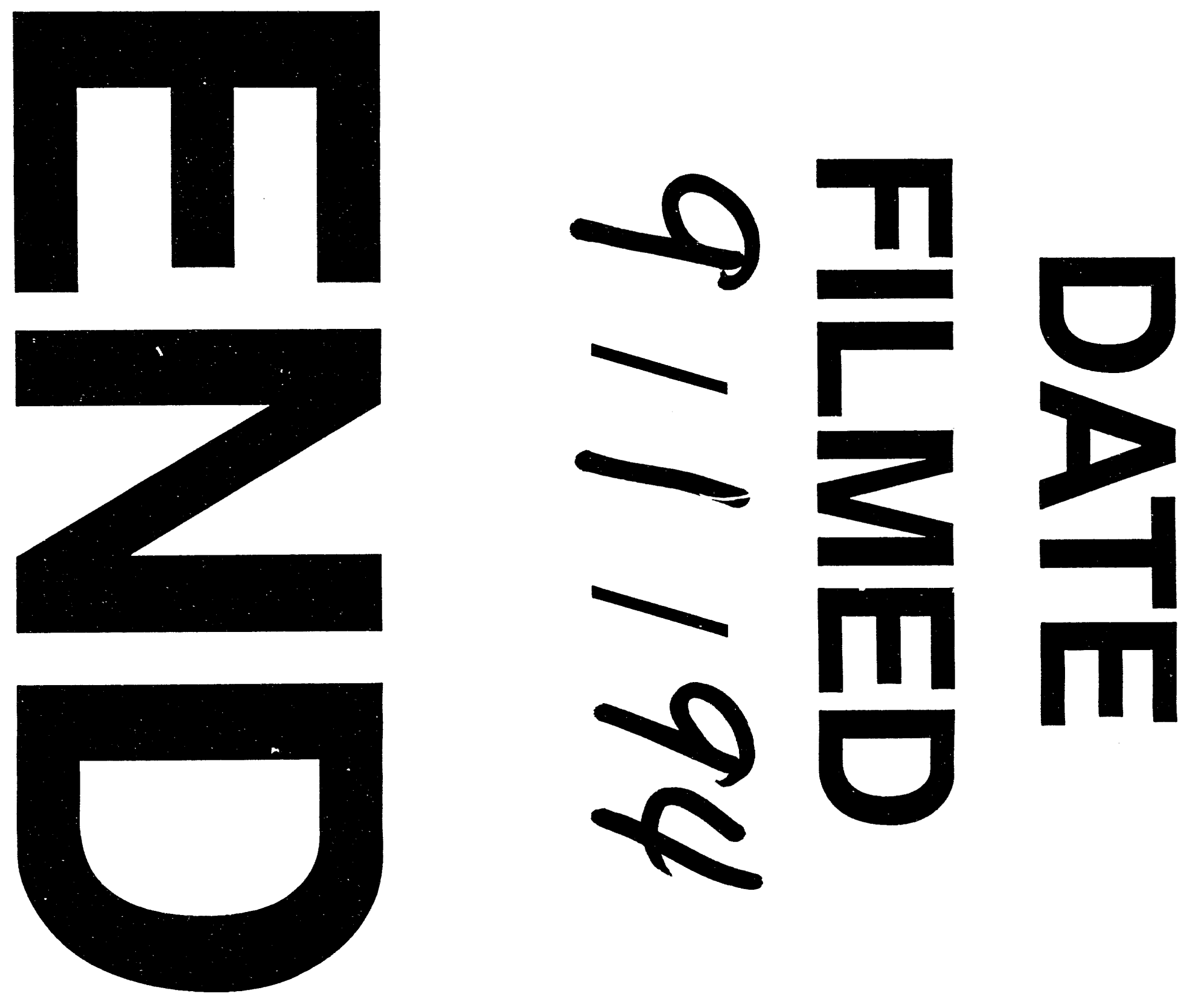
